\title{
PENGARUH FORMULA DAN PERBANDINGAN BUMBU SERBUK DENGAN SANTAN SERBUK TERHADAP KARAKTERISTIK BUMBU GULAI SERBUK DENGAN METODE FOAM-MAT DRYING
}

\author{
Neneng Suliasih \\ Ina Siti Nurminabari \\ Giga Ruhmiana Budia Kusuma \\ Program Studi Teknologi Pangan, Fakultas Teknik, Universitas Pasundan, Jl. Dr.Setiabudi No 93, Bandung, 40153, \\ Indonesia \\ E-mail : $\underline{n}$ suliasih@yahoo.com
}

\begin{abstract}
Abstrak
Tujuan dari penelitian ini adalah untuk mempelajari formula dan perbandingan bumbu serbuk dengan santan serbuk dalam pembuatan bumbu gulai serbuk dengan menggunakan metode foam-mat drying, sehingga diperoleh karakteristik yang baik yang dapat di manfaatkan untuk bumbu masakan gulai. Penelitian dilakukan dengan menggunakan Rancangan Acak Kelompok (RAK) yang terdiri dari 2 faktor A (Formula) yang terdiri dari 2 taraf yaitu a1 (formula 1), dan a2 (formula 2) dan faktor B (perbandingan bumbu serbuk dengan santan serbuk) yang terdiri dari 3 taraf yaitu b1 (1 $: 1,5)$, b2 (1: 1), dan b3 (1,5:1). Respon dalam penelitian adalah respon organoleptik (warna, aroma, dan rasa), respon kimia (kadar air dan kadar lemak), dan respon fisik (uji kadar rendemen). Berdasarkan hasil penelitian, diketahui bahwa formula berpengaruh terhadap warna, aroma, dan kadar lemak, perbandingan bumbu serbuk dengan santan serbuk berpengaruh terhadap warna, aroma, rasa, kadar air, dan kadar lemak serta interaksi antara formula dan perbandingan bumbu serbuk dengan santan serbuk berpengaruh terhadap aroma, rasa dan kadar lemak. Perlakuan terpilih yaitu produk bumbu gulai dengan menggunakan formula 2 (a2) dan perbandingan bumbu serbuk dengan santan serbuk (1,5:1) (b3) yang memiliki kadar air 10,88\%, kadar lemak 10,97\% dan kadar rendemen rata-rata untuk formula 2 (a2) sebesar $28,41 \%$.
\end{abstract}

\begin{abstract}
The purpose of this research is to study the formula and comparison of powdered herbs with coconut milk powder in the manufacture of spice curry powder using the method of foam-mat drying, to obtained good characteristics that can be utilized for gulai spices cooking. The research was conducted using group randomized design (RAK) consisting of 2 factor A (formula) consisting of 2 levels ie a1(formula 1), and a2 (formula 2) and factor B (comparison of powdered spice with coconut milk powder) consisting of 3 levels ie b1 (1:1,5), b2 (1:1), and b3 (1,5:1). Response in research is organoleptic response (color, flavor, and taste), chemical response (moisture content and fat content), and physical response (test of yield content). Based on the results of the research, it is known that the formula has an effect on color, aroma, and fat content, the ratio of spice powder with coconut milk The powder affects the color, flavor, taste, moisture content, and fat content as well The interaction between the formula and the ratio of powdered condiments affected to coconut milk powder affect the aroma, taste and fat content. The choosen methos for spice product are by using formula 2 (a2) and the ratio of powdered herbs to coconut milk powder $(1,5: 1)$ (b3) has a moisture content of $10,88 \%$, fat content of $10,97 \%$ and average yield content for formula 2 (a2) of $28,41 \%$.
\end{abstract}

Keyword: Spice curry powder, formula, comparison of powdered herbs with coconut milk powder

\section{Pendahuluan}

Menurut definisi dari Wikipedia, gulai adalah sejenis makanan berbahan baku daging ayam, aneka ikan, kambing, sapi, jenis daging lain, jeroan, atau sayuran seperti nangka muda dan daun singkong, yang dimasak dalam kuah bumbu rempah yang bercitarasa gurih. Ciri khas gulai adalah bumbunya yang kaya rempah antara lain kunyit, ketumbar, lada, lengkuas, jahe, cabai merah, bawang merah, bawang putih, adas, pala, serai, kayu manis dan jinan yang dihaluskan, dicampur, kemudian dimasak dalam santan. Masakan ini yang memiliki ciri khas berwarna kuning karena pengaruh sari kunyit. Makanan ini dianggap sebagai bentuk lain dari kari, dan secara internasional sering disebut sebagai kari ala Indonesia.

Menurut Prasetyo (2003), dewasa ini masyarakat menginginkan segala sesuatu yang serba cepat, mudah, dan praktis. Demikian pula dalam masalah makanan, masyarakat lebih menyukai yang dapat diolah dan disajikan dengan cepat dan mudah tetapi juga sesuai dengan selera mereka. Masakan Indonesia, seperti rawon, soto, rendang, dan lain-lain, umumnya rumit dan tidak dapat disajikan dengan cepat. Salah satu cara untuk menyajikannya dengan cepat dan mudah adalah 
dengan menggunakan bumbu siap pakai berbentuk pasta atau serbuk.

Bumbu instan di pasaran ada beberapa macam diantaranya bumbu berbentuk pasta dan bumbu berbentuk serbuk, bumbu pasta masih mengandung kadar air yang tinggi sedangkan bumbu serbuk adalah bumbu yang kadar airnya rendah karena adanya proses pengeringan dalam pembuatannya, sehingga bumbu serbuk umur simpannya lebih panjang bila dibandingkan dengan bumbu yang berbentuk pasta.

Adanya produk bumbu gulai serbuk akan mempermudah masyarakat dalam pembuatan gulai sehari-hari, terutama pada waktu hari raya besar seperti idul fitri, idul adha, dan juga memperpanjang umur simpan dari bumbu gulai itu sendiri. Namun yang menjadi kendala dikalangan masyarakat adalah formula dari setiap bahan yang digunakan untuk membuat bumbu gulai berbeda-beda setiap orang. Untuk mendapatkan citarasa yang sesuai membutuhkan formula yang tepat dari berbagai jenis rempah yang digunakan. Gulai identik dengan adanya penambahan santan, penambahan santan yang sesuai dapat menambah citarasa dari bumbu gulai yang pas.

Salah satu tujuan penggunaan metode foam-mat drying adalah untuk mempercepat proses pengeringan, karena pada metode pengeringan ini adanya penambahan bahan pembusa atau pembuih. Konsentrasi buih yang semakin banyak akan meningkatkan luas permukaan dan memberi struktur berpori pada bahan sehingga akan meningkatkan kecepatan pengeringan. Jenis-jenis pembusa diantaranya adalah putih telur (albumin), polysorbat 80, soda kue dan gliserin.

Menurut Kumalaningsih dkk (2005), dengan adanya busa maka akan mampercepat proses penguapan air walaupun tanpa suhu yang terlalu tinggi, produk yang dikeringkan menggunakan busa pada suhu 50$80^{\circ} \mathrm{C}$ dapat menghasilkan kadar air 2-3\%. Bubuk dari hasil metode foam-mat drying mempunyai densitas atau kepadatan yang rendah (ringan) dan bersifat remah.

\section{Metode Penelitian}

Penelitian dibagi menjadi 2 tahapan meliputi penelitian pendahuluan dan penelitian utama. Pada penelitian pendahuluan yang dilakukan yaitu menentukan konsentrasi putih telur yang digunakan sebagai bahan pembuih pembuatan bumbu gulai serbuk. Konsentrasi yang digunakan adalah $10 \%, 15 \%$, dan $20 \%$ dan perbandingan bumbu serbuk dengan santan yang digunakan adalah $(1: 1,5),(1: 1)$ dan $(1,5: 1)$.

Pengeringan dilakukan pada suhu $60^{\circ} \mathrm{C}$ dan waktu pengeringan 4 jam. Untuk menentukan konsentrasi terpilih dilakukan uji kadar air dan uji hedonik terhadap tiga konsentrasi tersebut. Pengujian dilakukan terhadap 30 orang panelis terhadap atribut mutu warna, aroma dan kenampakan.

Penelitian utama dilakukan untuk menentukan formula bumbu gulai pada formula 1 dan formula 2 , dan perbandingan bumbu sebuk dan santan serbuk yaitu (1 : $1,5),(1: 1)$ dan $(1,5: 1)$

Rancangan perlakuan pada penelitian ini terdiri dari dua faktor, yaitu : Formula yang terdiri dari 2 taraf dan perbandingan bumbu serbuk dengan santan serbuk yang terdiri dari 3 taraf.

Formula (A), terdiri dari 2 taraf, yaitu :

$\mathrm{a}_{1}=$ Formula 1

$\mathrm{a}_{2}=$ Formula 2

Perbandingan bumbu serbuk dan santan serbuk (B), terdiri dari 3 taraf, yaitu :

$$
\begin{aligned}
& b_{1}=1: 1,5 \\
& b_{2}=1: 1 \\
& b_{3}=1,5: 1
\end{aligned}
$$

Rancangan percobaan yang digunakan pada penelitian ini adalah Rancangan Acak Kelompok (RAK) dengan faktorial 2 x 3 dengan 4 kali pengulangan. Rancangan respon terdiri dari rancangan respon kimia, fisik dan organoleptik. Rancangan Respon kimia yang dilakukan terhadap produk bumbu gulai serbuk adalah penentuan kadar air metode gravimetri (AOAC, 2005), dan kadar lemak (AOAC, 2005). Respon fisik yang dilakukan, hanya pada faktor formula yang berbeda produk bumbu gulai serbuk adalah penentuan nilai rendemen. Uji organoleptik meliputi warna, aroma, dan rasa bumbu masak. Uji organoleptik ini dilakukan dengan metode penerimaan yaitu skala hedonik, dimana kriteria penilaian berdasarkan tingkat kesukaan panelis terhadap produk bumbu gulai serbuk yang diaplikasikan terhadap produk gulai ayam, yang dilakukan oleh 30 orang panelis dengan parameter yang digunakan dalam uji organoleptik ini meliputi atribut warna, aroma, dan rasa terhadap bumbu gulai serbuk yang telah diaplikasikan, dimasak dan disajikan seperti masakan gulai dengan perbandingan bumbu gulai serbuk dan air $1: 8$. Dengan cara memasak gulai yang pertama adalah siapkan daging ayam 100 gram kemudian rebus daging ayam terlebih dahulu sampai daging ayam tersebut manjadi empuk, kemudian masukan daging ayam ke dalam panci, tambahkan air $120 \mathrm{ml}$ dan tambahkan bumbu gulai serbuk yang telah ditambahkan santan serbuk sebanyak 15 gram kedalam panci, lalu masak dengan menggunakan api sedang selama 6 menit hingga kuah agak mengental, maka gulai siap di hidangkan.

\section{Hasil dan Pembahasan}

\section{Hasil Penelitian Pendahuluan}

1. Uji Organoleptik

a. Warna

Hasil analisis sumber variansi (ANAVA), menunjukkan konsentrasi putih telur tidak berpengaruh terhadap warna bumbu gulai serbuk. Hal ini disebabkan karena warna coklat kekuningan pada bumbu gulai serbuk yang dihasilkan lebih dominan dan menurut panelis, warna bumbu gulai serbuk yang dihasilkan memiliki warna yang sama yaitu coklat kekuningan.

Atribut warna pada bumbu gulai serbuk yang dihasilkan memiliki warna yang mirip satu sama lain 
dikarenakan formula yang digunakan sama dan persentase setiap bahan yang digunakan tidak berbeda jauh, warna pada bumbu gulai serbuk dipengaruhi dari cabai merah yang digunakan, persentase dari cabai merah yang digunakan cukup tinggi dari bahan yang lainnya. Menurut Sudaryati (2013) warna bubuk cabai adalah merah kekuningan karena di dalam cabai mengandung pigmen karotenoid yaitu pigmen yang berwarna merah kekuningan. Warna kuning juga dihasilkan dari kunyit, zat warna kuning pada kunyit yaitu kurkumin.

\section{b. Aroma}

Hasil analisis sumber variansi (ANAVA), konsentrasi putih telur tidak berpengaruh terhadap aroma bumbu gulai serbuk. Hal ini disebabkan karena aroma yang dihasilkan bumbu gulai serbuk memiliki aroma rempah-rempah yang dominan, dan aroma bumbu gulai serbuk yang dihasilkan memiliki aroma yang sama yaitu aroma rempah-rempah.

Atribut aroma pada bumbu gulai serbuk yang dihasilkan memiliki aroma yang mirip satu sama lain dikarenakan formula yang digunakan sama dan persentase setiap bahan yang digunakan tidak berbeda jauh, aroma pada bumbu gulai serbuk dipengaruhi oleh beberapa rempah yang terkandung didalamnya. Semakin tinggi konsentrasi rempah yang diberikan akan menghasilkan aroma yang lebih harum yang berasal dari minyak atsiri yang terkandung dalam bumbu seperti lengkuas, jahe, kunyit dan bawang putih, penambahan berbagai macam rempah selain dapat menghasilkan aroma yang khas juga dapat meningkatkan daya awet bumbu (Raghavan, 2007).

\section{c. Kenampakan}

Hasil analisis sumber variansi (ANAVA), menunjukkan konsentrasi putih telur tidak berpengaruh terhadap kenampakan bumbu gulai serbuk. Hal ini disebabkan karena menurut panelis, kenampakan bumbu gulai serbuk yang dihasilkan memiliki kenampakan yang seragam dari segi warna maupun bentuk butiran yang seragam. Hal ini disebabkan karena bahan baku yang digunakan pada setiap perlakuan menggunakan bahan yang sama dengan perbedaan persentase yang tidak berbeda jauh.

Kriteria kenampakan merupakan parameter organoleptik yang cukup penting dinilai oleh panelis. Hal ini disebabkan jika kesan kenampakan baik dan disukai, maka panelis akan melihat parameter organoleptik yang lainnya (aroma, tekstur, dan rasa).

Kenampakan juga mempengaruhi penerimaan konsumen, meskipun kenampakan tidak menentukan tingkat kesukaan konsumen secara mutlak, keseragaman dan keutuhan suatu produk tentunya akan menarik panelis dan lebih disukai jika dibandingkan dengan produk yang beragam dan tidak utuh (Soekarto, 1985).

\section{Kadar Air}

Berdasarkan hasil analisis kadar air dengan menggunakan metode gravimetri, konsentrasi putih telur $10 \%, 15 \%$ dan $20 \%$ menunjukkan hasil kadar air yang berbeda, dengan kadar air terendah yaitu pada konsentrasi putih telur $20 \%$ dengan $4,33 \%$. Hasil analisis pendahuluan kadar air rata-rata dapat dilihat pada tabel 4 .

Tabel 4. Hasil Analisis Pendahuluan Uji Kadar Air Bumbu Gulai Serbuk

\begin{tabular}{|l|l|}
\hline $\begin{array}{l}\text { Konsentrasi putih } \\
\text { telur }\end{array}$ & Kadar air (\%) \\
\hline $10 \%$ & 6,00 \\
\hline $15 \%$ & 5,00 \\
\hline $20 \%$ & 4,33 \\
\hline
\end{tabular}

Berdasarkan data pada tabel 4 kadar air dengan menggunakan gravimetri menunjukkan kadar air dengan konsentrasi putih telur $10 \%$ rata-rata kadar air yang diperoleh sebesar $6,00 \%$, pada konsentrasi putih telur $15 \%$ didapat rata-rata kadar air sebesar 5,00\%, dan pada konsentrasi putih telur $20 \%$ menunjukkan kadar air yang paling rendah yaitu $4,33 \%$. Dilihat dari hasil tersebut semakin tinggi konsentrasi putih telur maka semakin rendah kadar air dari produk bumbu gulai serbuk. Hal ini disebabkan karena semakin tinggi konsentrasi putih telur maka semakin banyak molekul air yang menguap dari bumbu gulai serbuk yang dikeringkan sehingga kadar air yang diperoleh semakin rendah. Hal tersebut juga diungkapkan oleh Menurut Mulyoharjo (1988), bahwa konsentrasi busa (putih telur) yang semakin banyak akan meningkatkan luas permukaan dan memberi struktur berpori pada bahan sehingga akan meningkatkan kecepatan pengeringan. Lebih lanjut Van Arsdel et al., (1973), menyatakan bahwa lapisan pada pengeringan busa lebih cepat kering dari pada lapisan tanpa busa pada kondisi yang sama.

Faktor yang sangat berpengaruh terhadap penurunan mutu produk pangan adalah perubahan kadar air dalam produk. Aktivitas air (aw) berkaitan erat dengan kadar air, yang umumnya digambarkan sebagai kurva isotermis, serta pertumbuhan bakteri, jamur dan mikroba lainnya. Makin tinggi aw pada umumnya makin banyak bakteri yang dapat tumbuh, sementara jamur tidak menyukai aw yang tinggi, maka semakin rendah kadar air dalam suatu bahan akan semakin baik dalam daya tahan dan umur simpan bahan tersebut (Herawati, 2008).

Berdasarkan uji organoleptik terhadap atribut warna, aroma, dan kenampakan yang tidak berbeda nyata dan hasil analisis kadar air yang semakin rendah akan semakin baik terhadap bahan pangan maka konsentrasi putih telur $20 \%$ yang menunjukkan hasil kadar air dengan rata-rata terendah yaitu $4,33 \%$ akan digunakan pada penelitian utama pembuatan bumbu gulai serbuk dengan metode foam-mat drying. Pemilihan kadar air yang paling rendah yaitu 4,33\% 
karena semakin rendah kadar air yang diperoleh akan membuat umur simpan bumbu gulai serbuk lebih lama, dan apabila dilakukan penambahan santan serbuk kadar air bumbu gulai serbuk masih dapat diterima oleh standar SNI yaitu dibawah $12 \%$.

\section{Hasil Penelitian Utama}

1. Uji Organoleptik

a. Warna

Berdasarkan hasil analisis sumber variansi (ANAVA), menunjukkan perlakuan formula (A) dan perbandingan bumbu serbuk dengan santan serbuk (B) berpengaruh nyata terhadap warna bumbu gulai serbuk, sedangkan interaksi antara formula (A) dan perbandingan bumbu serbuk dengan santan serbuk (B) tidak berpengaruh nyata terhadap warna bumbu gulai serbuk yang telah diaplikasikan. Pengaruh formula (A) terhadap warna produk bumbu gulai serbuk dapat dilihat pada tabel 5 .

Tabel 5. Pengaruh Formula (A) Terhadap Atribut Warna Bumbu Gulai Serbuk

\begin{tabular}{|c|c|}
\hline Formula (A) & $\begin{array}{c}\text { Nilai Rata - Rata Atribut } \\
\text { Warna }\end{array}$ \\
\hline a1 (Formula 1) & $4,258 \mathrm{a}$ \\
\hline a2 (Formula 2) & 4,614 b \\
\hline
\end{tabular}

Keterangan : Nilai rata-rata yang ditandai dengan huruf berbeda menandakan perbedaan nyata pada Uji Lanjut Duncan 5\%

Berdasarkan data pada tabel 5 menunjukkan bahwa formula 2 (a2) lebih disukai dibandingkan dengan formula 1 (a1) dalam atribut warna, karena formula 2 memiliki warna coklat tua bila dibandingkan dengan formula formula 1 yang berwarna kuning kemerahan. Faktor yang mempengaruhi atribut warna bumbu gulai serbuk yaitu bahan baku cabai dan kunyit, pada formula 1 persentase cabai merah lebih banyak dibandingkan bahan lainnya yang akan membuat warna dari bumbu gulai lebih kuning kemerahan. Lebih lanjut Saadah (2016), mengungkapkan bahwa cabai memiliki kandungan warna $\beta$-karoten yang dapat menyebankan warna merah kekuningan pada olahan bahan pangan. Kunyit memiliki zat warna kurkumin (diferuloylmethane) (3-4\%) merupakan komponen aktif dari kunyit yang berperan untuk warna kuning, dan terdiri dari kurkumin I (94\%), kurkumin II (6\%) dan kurkumin III (0,3\%) (Fitrikaniawati, 2012). Pengaruh perbandingan bumbu serbuk dengan santan serbuk (B) terhadap atribut warna bumbu gulai serbuk dapat dilihat pada tabel 6 .

Berdasarkan data pada tabel 6 menunjukkan bahwa perbandingan bumbu serbuk dengan santan serbuk b3 (1,5: 1) lebih disukai dibandingkan dengan b1 $(1: 1,5)$ dan b2 (1: 1). Karena warna pada perbandingan bumbu serbuk dengan santan serbuk b3 (1,5:1) memiliki warna coklat, dibandingkan dengan perlakuan b1 $(1: 1,5)$ dan b2 (1: 1) yang memiliki warna coklat kehitaman. Penambahan santan dengan perbandingan yang berbeda dapat mempengaruhi warna pada gulai yang telah diaplikasikan dan dimasak, karena pada proporsi santan yang lebih banyak membuat warna produk gulai menjadi lebih gelap. Hal tersebut juga diungkapkan juga oleh Cahyono (2015), penambahan santan dengan proporsi yang berbeda berpengaruh terhadap warna penambahan santan yang lebih banyak mengakibatkan warna masakan terlalu gelap dan tidak dapat diterima oleh panelis. Diketahui pula bahwa santan memiliki kandungan protein yang lebih banyak dan kandungan karbohidrat, adanya kandungan protein dan karbohidrat dapat menyebabkan terjadinya reaksi maillard. Raksi maillard merupakan reaksi antara gugus aldehid dari karbohidrat dengan gugus amino dari protein yang disebabkan karena adanya pemanasan. Adanya reaksi maillard tersebut menyebabkan terjadinya perubahan warna yang disebut dengan browning (Jing, dkk 2009).

Tabel 6. Pengaruh Perbandingan Bumbu Serbuk Dengan Santan Serbuk (B) Terhadap Atribut Warna Bumbu Gulai Serbuk

\begin{tabular}{|c|c|}
\hline $\begin{array}{l}\text { Perbandingan bumbu serbuk } \\
\text { dengan santan serbuk (B) }\end{array}$ & Nilai Rata - Rata warna \\
\hline b1 $(1: 1,5)$ & $4,417 \mathrm{a}$ \\
\hline b2 $(1: 1)$ & $4,408 \mathrm{a}$ \\
\hline b3 $(1,5: 1)$ & $4,483 \mathrm{~b}$ \\
\hline
\end{tabular}

Keterangan : Nilai rata-rata yang ditandai dengan huruf berbeda menandakan perbedaan nyata pada Uji Lanjut Duncan 5\%

\section{b. Aroma}

Tabel 7. Interaksi Antara Pengaruh Faktor Formula (A) Dengan Perbandingan Bumbu Serbuk Dengan Santan Serbuk (B) Terhadap Atribut Aroma Bumbu Gulai Serbuk|

\begin{tabular}{|c|c|c|c|}
\hline \multirow[b]{2}{*}{ Formula } & \multicolumn{3}{|c|}{$\begin{array}{l}\text { Perbandingan bumbu dengan santan } \\
\text { serbuk }\end{array}$} \\
\hline & b1 $(1: 1,5)$ & $\mathrm{b} 2(1: 1)$ & p3 (1,5: 1) \\
\hline a1 & $\begin{array}{lll} & \mathrm{A} \\
& 4,26 & \\
\mathrm{a} & & \\
\end{array}$ & $\begin{array}{ll} & \text { B } \\
& 4,48 \\
\text { b } & \\
\end{array}$ & 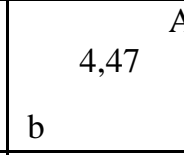 \\
\hline a2 & $\begin{array}{ll} & \mathrm{A} \\
& 4,58^{-1} \\
\mathrm{~b} & \\
\end{array}$ & 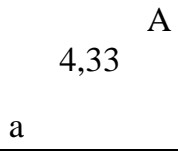 & 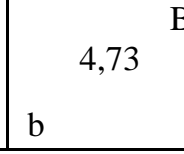 \\
\hline
\end{tabular}

Keterangan: Huruf kecil dibaca arah horizontal dan huruf besar dibaca vertikal, huruf yang berbeda menyatakan perbedaan yang nyata pada taraf $5 \%$ uji lanjut Duncan.

Berdasarkan hasil analisis sumber variansi (ANAVA), menunjukkan faktor formula (A) dan perbandingan bumbu serbuk dengan santan serbuk (B) berpengaruh nyata terhadap aroma bumbu gulai serbuk, dan interaksi antara faktor formula (A) dan perbandingan bumbu serbuk dengan santan serbuk (B) 
berpengaruh nyata terhadap aroma bumbu gulai serbuk yang telah diaplikasikan. Pengaruh formula (A) dan perbandingan bumbu serbuk dengan santan serbuk (B) terhadap atribut warna dapat dilihat pada tabel 7 .

Berdasarkan data pada tabel 7 menunjukkan bahwa pada penambahan bumbu serbuk yang lebih banyak lebih disukai. Pada formula 1 dengan perbandingan bumbu serbuk dengan santan serbuk (1 : 1) lebih disukai dibandingkan dengan perbandingan bumbu serbuk dengan santan serbuk $(1: 1,5)$ dan $(1,5$ : 1). Pada formula 2 dengan perbandingan bumbu serbuk dengan santan serbuk (1,5: 1) lebih disukai dibandingkan dengan perbandingan bumbu serbuk dengan santan serbuk $(1: 1,5)$ dan $(1: 1)$, perbandingan bumbu serbuk yang lebih banyak lebih disukai karena aroma rempahrempah dari gulai lebih dominan. Faktor yang mempengaruhi atribut aroma bumbu gulai serbuk yaitu bahan baku, diantaranya daun salam, serai, daun jeruk, cengkih dan kapulaga. Pura (2015) mengungkapkan bahwa daun salam mengandung minyak atsiri yang mengandung aroma yang khas. Daun salam dapat menghasilkan minyak atsiri yang memiliki aroma harum dan dapat digunakan sebagai penyedap masakan (Sembiring,

2003).

Adanya serai juga mempengaruhi aroma dari bumbu gulai itu sendiri Menurut Agusta (2002), serai memiliki aroma yang cukup tajam dikarenakan serai mengandung minyak atsiri dengan komponen utamanya sitronelol, geraniol, geranial dan neral. Begitu juga dengan adanya daun jeruk, menurut Munawaroh (2010) minyak atsiri yang berasal dari daun jeruk disebut combava petitgrain (dalam bahasa afrika) yang banyak digunakan dalam industri makanan yang berfungsi untuk memberi aroma yang khas pada masakan. Cengkih juga berperan dalam memberikan aroma yang khas pada bumbu gulai, senyawa yang terdapat pada cengkih menurut Kardinan (2005) adalah senyawa eugenol yang merupakan cairan bening hingga kuning pucat, dengan aroma menyegarkan dan pedas, yang memberikan aroma yang khas cengkeh yang terdapat dalam makanan. Kapulaga juga memberikan aroma yang khas pada makanan, menurut Nirmagustina (2011), kapulaga memilika aroma bau sedap. Aroma sedap ini berasal dari kandungan minyak atsiri pada kapulaga. Minyak atsiri ini mengandung lima zat utama, yaitu borneol yang berbau seperti getah pohon kamper dan limonene yang juga harum seperti bau jeruk, alfa terpinen yang bau seperti jeruk sitrun, cineol yang sedap agak pedas menghangatkan seperti minyak kayu putih, kombinasi inilah yang membentuk bau khas dari kapulaga.

\section{c. Rasa}

Tabel 8. Interaksi Antara Pengaruh Faktor Formula (A) Dengan Perbandingan Bumbu Serbuk Dengan Santan Serbuk (B) Terhadap Atribut Rasa Bumbu Gulai Serbuk

\begin{tabular}{|c|c|c|c|}
\hline \multirow[b]{2}{*}{ Formula } & \multicolumn{3}{|c|}{$\begin{array}{l}\text { Perbandingan bumbu dengan santan } \\
\text { serbuk }\end{array}$} \\
\hline & $b 1(1: 1,5)$ & $\mathrm{b} 2(1: 1)$ & b3 $(1,5: 1)$ \\
\hline a1 & ${ }_{4,058}$ A & $\begin{array}{r}\text { B } \\
4,258 \\
a\end{array}$ & $4,242 \quad$ A \\
\hline $\mathrm{a} 2$ & $\begin{array}{l}\text { B } \\
4,358 \\
b\end{array}$ & $a{ }^{\mathrm{A}}$ & B 5,050 \\
\hline
\end{tabular}

Keterangan: Huruf kecil dibaca arah horizontal dan huruf besar dibaca vertikal, huruf yang berbeda menyatakan perbedaan yang nyata pada taraf $5 \%$ uji lanjut Duncan.

Berdasarkan hasil analisis sumber variansi (ANAVA), menunjukkan faktor formula (A) tidak berpengaruh nyata terhadap atribut rasa bumbu gulai serbuk namun perbandingan bumbu serbuk dengan santan serbuk (B) berpengaruh nyata terhadap warna bumbu gulai serbuk, dan interaksinya antara faktor formula (A) dan perbandingan bumbu serbuk dengan santan serbuk (B) berpengaruh nyata terhadap warna bumbu gulai serbuk yang telah diaplikasikan.

Berdasarkan data pada tabel 8 menunjukkan bahwa pada formula 1 (a1) dengan perbandingan bumbu serbuk dengan santan serbuk b2 (1: 1) lebih disukai karena memiliki rasa gurih yang pas dan tidak berlebihan dibandingkan dengan perbandingan bumbu serbuk dengan santan serbuk b1 $(1: 1,5)$ dan b3 $(1,5$ : 1). Pada formula 2 (a2) dengan perbandingan bumbu serbuk dengan santan serbuk b3 ( $1,5: 1)$ lebih disukai karena rasa dari rempah-rempah lebih dominan dan rasa gurih yang di hasasilkan tidak berlebih, bila dibandingkan dengan perbandingan bumbu serbuk dengan santan serbuk b1 (1: 1,5) dan b2 (1: 1) yang rasa rempah-rempahnya tidak terlalu dominan.

Penambahan bumbu serbuk yang lebih banyak akan memberikan rasa dari rempah-rempah yang lebih dominan dan dengan penambahan santan serbuk yang pas akan membuat rasanya lebih gurih. Hal ini juga diungkapkan dalam penelitiannya oleh Cahyono (2015), santan mempunyai rasa lemak dan digunakan sebagai perasa yang menyedapkan masakan menjadi gurih. Santan akan menambah rasa gurih karena kandungan lemaknya yang tinggi. Pada penelitiannya mengungkapkan bahwa panelis menyukai penambahan santan yang lebih sedikit dibandingkan penambahan santan yang lebih banyak menimbulkan rasa gurih yang berlebih sehingga konsumen tidak dapat menerimanya.

\section{Kadar Air}

Hasil analisis sumber variansi (ANAVA), menunjukkan faktor formula (A) tidak berpengaruh nyata terhadap kadar air bumbu gulai serbuk namun perbandingan bumbu serbuk dengan santan serbuk (B) berpengaruh nyata terhadap warna bumbu gulai serbuk, 
dan interaksinya antara faktor formula (A) dengan santan serbuk (B) tidak berpengaruh nyata terhadap kadar air bumbu gulai serbuk, pengaruh perbandingan bumbu serbuk dengan santan serbuk (B) terhadap kadar air bumbu gulai serbuk dapat dilihat pada tabel 9 .

Tabel 9. Pengaruh Perbandingan Bumbu Serbuk Dengan Santan Serbuk (B) Terhadap Kadar Air Bumbu Gulai Serbuk

\begin{tabular}{|c|c|}
\hline $\begin{array}{l}\text { Perbandingan bumbu serbuk } \\
\text { dengan santan serbuk (B) }\end{array}$ & Kadar Air (\%) \\
\hline b1 $(1: 1,5)$ & $9,88 \mathrm{a}$ \\
\hline b2 $(1: 1)$ & $10,63 \mathrm{ab}$ \\
\hline b3 $(1,5: 1)$ & $10,94 \mathrm{~b}$ \\
\hline
\end{tabular}

Keterangan : Nilai rata-rata yang ditandai dengan huruf berbeda menandakan perbedaan nyata pada Uji Lanjut Duncan 5\%

Berdasarkan data pada tabel 9 menunjukkan bahwa kadar air pada perlakuan perbandingan bumbu serbuk dengan santan serbuk b1 $(1: 1,5)$ berbeda nyata dengan perbandingan bumbu serbuk dengan santan serbuk b3 (1,5:1), namun b1 $(1: 1,5)$ tidak berbeda nyata dengan b2 $(1: 1)$ dalam kadar air bumbu gulai serbuk. Kadar air produk bumbu gulai serbuk pada perlakuan perbandingan bumbu serbuk dengan santan serbuk b1 (1 : 1,5) memiliki kadar air yang paling rendah yaitu 9,88 \% dibandingkan dengan perlakuan perbandingan bumbu serbuk dengan santan serbuk b2 (1 : 1) yaitu $10,63 \%$ dan perlakuan perbandingan bumbu serbuk dengan santan serbuk b3 (1,5:1) yaitu $10,94 \%$.

Semakin tinggi penambahan santan serbuk semakin rendah kadar air yang terdapat pada bumbu gulai serbuk, santan serbuk memiliki kadar air yang sangat rendah bila dibandingkan dengan kadar air bumbu gulai serbuk yaitu sebesar 1,39 - 3,06 \% (Prasetio, 2014). Bila dibandingkan dengan kadar air pada bumbu gulai serbuk yang dihasilkan, kadar air santan serbuk lebih rendah sehingga ketika penambahan santan yang lebih banyak kadar air yang dihasilkan pada bumbu gulai serbuk yang telah dicampurkan dengan santan serbuk akan lebih rendah bila dibandingkan dengan penambahan santan serbuk yang lebih sedikit.

\section{Kadar Lemak}

Hasil analisis sumber variansi (ANAVA), menunjukkan faktor formula (A) dan perbandingan bumbu serbuk dengan santan serbuk (B) berpengaruh nyata terhadap kadar lemak bumbu gulai serbuk, dan interaksi antara faktor formula (A) dan perbandingan bumbu serbuk dengan santan serbuk (B) berpengaruh nyata terhadap kadar lemak bumbu gulai serbuk.

Interaksi antara faktor formula (A) dan perbandingan bumbu serbuk dengan santan serbuk (B) dapat dilihat pada tabel 10 .

Tabel 10. Interaksi Antara Pengaruh Faktor Formula (A) Dengan Perbandingan Bumbu Serbuk Dengan Santan
Serbuk (B) Terhadap Kadar Lemak Bumbu Gulai Serbuk

\begin{tabular}{|c|c|c|c|}
\hline \multirow[b]{2}{*}{ Formula } & \multicolumn{3}{|c|}{ dingan bumbu dengan santan serbuk } \\
\hline & b1 $(1: 1,5)$ & $\mathrm{b} 2(1: 1)$ & b3 $(1,5: 1)$ \\
\hline a1 & $\begin{array}{ll} & \mathrm{A} \\
\mathrm{b} & \\
& \end{array}$ & $\begin{array}{l}\text { B } \\
17,11 \\
b\end{array}$ & $\begin{array}{l}\text { B } \\
14,37^{-} \\
\text {a }\end{array}$ \\
\hline $\mathrm{a} 2$ & $\begin{array}{l}\text { B } \\
19,32^{-} \\
b\end{array}$ & ${ } 14,56^{\mathrm{A}}$ & $\begin{array}{ll} & \mathrm{A} \\
\mathrm{a} & \end{array}$ \\
\hline
\end{tabular}

Keterangan: Huruf kecil dibaca arah horizontal dan huruf besar dibaca vertikal, huruf yang berbeda menyatakan perbedaan yang nyata pada taraf 5\% uji lanjut Duncan.

Berdasarkan data pada tabel 10 menunjukkan bahwa semakin tinggi penambahan santan serbuk maka kadar lemak yang didapatkan juga semakin tinggi. Pada formula 1 (a1) dengan perbandingan bumbu serbuk dengan santan serbuk b1 (1: 1,5) kadar lemak lebih tinggi yaitu $18,68 \%$. Hal yang sama juga terjadi pada formula 2 (a2) dengan perbandingan bumbu serbuk dengan santan serbuk b1 (1: 1,5) kadar lemak lebih tinggi yaitu $19,32 \%$. Sedangkan untuk penambahan santan yang lebih rendah kadar lemak yang dihasilkan juga akan lebih kecil yaitu pada perbandingan bumbu serbuk dengan santan serbuk b3 (1,5:1) pada formula 1 (a1) sebesar $14,37 \%$ dan formula 2 (a2) sebesar $10,97 \%$.

Perbedaan formula 1 dan formula 2 yang paling membedakan adalah konsentrasi cabai merah yang digunakan, dimana pada formula 1 menggunakan konsentrasi cabai merah lebih banyak dibandingkan dengan formula 2. Menurut Ashari (2006), Cabai merah mengandung kadar lemak 0,3 gram dalam 100 gram bahan. Dan semakin tinggi penambahan santan maka kadar lemak nya yang didapatkan semakin tinggi pula. Hal ini dikarenakan kandungan lemak pada santan yang cukup tinggi. Menurut Srihari, dkk (2010) Santan kelapa mengandung tiga nutrisi utama, yaitu lemak sebesar $88,3 \%$, protein sebesar $6,1 \%$ dan karbohidrat sebesar $5,6 \%$.

\section{Uji Rendemen}

Berdasarkan hasil analisis uji kadar rendemen menunjukkan hasil kadar rendemen yang berbeda, hasil rata-rata analisis kadar rendemen dapat dilihat pada tabel 11 .

Tabel 11. Hasil Analisis Kadar Rendemen Bumbu Gulai Serbuk

\begin{tabular}{|c|c|}
\hline Formula & Kadar Rendemen (\%) \\
\hline Formula 1 & 23,43 \\
\hline Formula 2 & 28,41 \\
\hline
\end{tabular}


Berdasarkan data pada tabel 11 menunjukan bahwa kadar rendemen rata-rata yang dihasilkan oleh formula 2 lebih tinggi yaitu sebesar 28,41\% dibandingkan dengan formula 1 yaitu sebesar 23,41\%. Kadar rendemen yang dihasilkan formula 1 lebih rendah dikarenakan bahan baku yang digunakan pada formula 1 lebih banyak menggunakan cabai merah, sehingga pada saat proses pengeringan dengan suhu dan waktu yang sama hasilnya akan berbeda, karena ketika cabai merah dikeringkan, berat bahan kering cabai merah akan sangat ringan dibandingkan dengan berat bahan lainnya.

\section{Uji Perlakuan Terpilih}

Berdasarkan uji organoleptik terhadap bumbu gulai serbuk yang telah diaplikasikan, perlakuan a2b3 (formula 2 dan perbandingan bumbu serrbuk dengan santan serbuk $1,5: 1)$ merupakan perlakuan terpilih. Hal tersebut dikarenakan perlakuan a2b3 (formula 2 dan perbandingan bumbu serrbuk dengan santan serbuk 1,5: 1) lebih disukai oleh panelis dalam hal warna, aroma, dan rasa dan didukung dengan kadar lemak yaitu sebesar $10,97 \%$, kadar air $10,88 \%$ dan nilai rendemen formula 2 (a2) yaitu $28,41 \%$.

Berdasarkan hasil penelitian, dapat diambil kesimpulan sebagai berikut :

1. Berdasarkan penelitian pendahuluan, konsentrasi putih telur sebagai foaming agent yang terpilih adalah konsentrasi telur $20 \%$ yang menunjukkan hasil kadar air rata-rata yaitu $4,07 \%$.

2. Faktor formula (A) memberikan pengaruh nyata terhadap warna, aroma, dan kadar lemak, tetapi tidak berpengaruh nyata terhadap rasa dan kadar air.

3. Faktor perbandingan bumbu serbuk dengan santan serbuk (B) memberikan pengaruh nyata terhadap warna, aroma, rasa, kadar air, dan kadar lemak.

4. Interaksi antara faktor formula (A) dan perbandingan bumbu serbuk dengan santan serbuk (B) memberikan pengaruh nyata terhadap aroma, rasa dan kadar lemak.

5. Dari keseluruhan respon diperoleh perlakuan terpilih berdasarkan organoleptik yaitu a2b3 (formula 2 dan Perbandingan bumbu serbuk dengan santan serbuk 1,5: 1), dengan kadar air 10,88\%, kadar lemak 10,97\% dan nilai rendemen pada formula 2 (a2) yaitu $28,41 \%$.

\section{Daftar Pustaka}

1. Agusta, A. (2002). Aromaterapi Cara Sehat Dengan Wewangian Alami. Cetakan 2. PT. Penebar Swadaya. Jakarta

2. Aisha, E. Z., E. Zubaidah., dan D. W. Ningtyas. (2003). Pembuatan Kefir Bubuk dengan Metode Foam-Mat Drying (Kajian Proporsi Buih Putih Telur dan Konsentrasi Dekstrin). Jurusan Teknologi Hasil Pertanian. Fakultas Teknologi Pertanian. Universitas Brawijaya.

3. Ashari, S. (2006). Hortikultura, Aspek Budidaya. Edisi revisi. UI Press. Jakarta. 490 hal.
4. AOAC. (1990). Official Methods of Analisis. Association of Official Analitycal Chemist. AOAC. Washington DC. USA

5. Alawiah, W. (2010). Gini Lho, Varian Masakan Kambing Yang Mantappp. FlashBook. Yogyakarta

6. Astawan. (2009). Sehat dengan Kacangkacangan dan Biji-bijian. Penebar Swadaya. Jakarta. Badan Standarisasi Nasional. (1995). SNI 01-3709-1995 tentang RempahRempah Bubuk. Standar Nasional Indonesia. Jakarta.

7. Boga, Y. (2010). Koleksi $120 \quad$ Resep Masakan Ayam. PT.Gramedia Pustaka Utama.

8. Cahyono, M. A., dan S. Y. Sudarminto. (2015). Pengaruh Proporsi Santan dan Lama Pemanasan Terhadap Sifat Fisiko Kimia dan Organoleptik Bumbu Gado-gado Instan. Jurnal Pangan dan Agroindustri Vol. 3 No 3 p.1095-1106.

9. Ernawati, A. S. (2010). Dapur Pintar. Kawahmedia. Jakarta.

10. Gonnissen, Y., J. P. Remon., and C. Vervaet. (2008). Effect of Maltodextrin And Superdisintegrant In Directly Compressible Powder Mixtures Prepared Via Co-Spray Drying. European Journal of Pharmaceutics and Biopharmaceutics 68:277-282

11. Hambali, E., Fatmawati., dan R. Permanik. (2008). Membuat Aneka Bumbu Instan Kering. Penebar Swadaya. Jakarta.

12. Hartomo, A. J. dan M. C. Widiatmoko. (1993). Emulsi dan Pangan Instant Berlesitin. Andi Offset. Yogyakarta.

13. Haryanto, B. (2016). Pengaruh Konsentrasi Putih Telur Terhadap Sifat Fisik, Kadar Antosianin dan Aktivitas Antioksidan Bubuk Instan Ekstrak Kulit Manggis (Garcinia Mongostana L) Dengan Metode Foam-Mat Drying. Wiyaiswara Balai Pelatihan Pertanian. Lampung.

14. Herawati H. (2008). Penentuan Umur Simpan Pada Produk Pangan. Jurnal Litbang Pertanian 27(4): 124130.

15. Isnaeni, M. F., Y. Irawan., dan Harvelly. (2016). Konsentrasi Penstabil (Maltodekstrin dan Gum Arab) dan Putih Telur terhadap Karakteristik Serbuk Nanas Yang Dibuat Dengan Metode FoamMat Drying. Jurusan Teknologi Pangan. Fakultas Teknik Universitas Pasundan. Bandung.

16. Jing., H. M. Yap., P. Y. Y. Wong., and D. D. Kitts. (2009). Comparison of physicochemical and antioxidant properties of egg-white proteins and fructose and inulin Maillard reaction products. Food Bioprocess Tech., 11: 269-279.

17. Kardinan, A. (2005). Tanaman Penghasil Minyak Atsiri. Agromedia Pustaka, Jakarta. 74 hlm.

18. Karim, A. A., dan C. C. Wai. (1999). Foam Mat Drying Starfruit (Avverhoa Carambola L) Pure. 
Stability and Air Drying Characteristic. J. Food Chemistry.

19. Ketaren, S. (1986). Pengantar Teknologi Minyak dan Lemak Pangan. Cetakan Pertama. Jakarta. UIPress.

20. Kumalaningsih. (2005). Potensi Daun Suji (Pleomele Angustifolia) Sebagai Serbuk Pewarna Alami (Kajian Konsentrasi Dekstrin dan Putih Telur Terhadap Karakteristik Serbuk). Jurnal Jurusan Teknologi Industri Pertanian. Fakultas Teknologi Pertanian. Universitas Brawijaya.

21. Maryam, S. (1993). Kadar Protein dalam Ampas Santan Kelapa Pada Proses Pembuatan Minyak Kelapa Secara Sederhana. Program Studi Pendidikan Kimia Jur. Dik Kimia MIPA, IKIP Udayana.

22. Mulyoharjo, M., dan D. Wijoyono. (1998). Teknologi Pengawetan Pangan

(Terjemahan dari Desrosier, N. W). Universitan Indonesia Press. Jakarta.

23. Munawaroh, S. Dan A. H. Prima. (2010). Ekstraksi Minyak Daun Jeruk Purut (Cytrus hystrix D.C.) dengan Pelarut Etanol dan N-hexan. Jurnal kompetensi Teknik Vol. 2 No. 1.

24. Nirmagustina, D. E., Zulfahmi., dan Oktafrina. (2011). Sifat Organoleptik dan Kandungan Total Fenol Minuman Rempah Tradisional (Minuman Secang). Lampung: Program Studi Teknologi Pangan Politeknik Negeri Lampung.

25. Prasetio, A. A., B. O. Anggraini., D. E. Prasetya., Saputri, dan Y. F. Rohman. (2014). Pengaruh Santan Segar dan Santan Instan Terhadap Mutu Organoleptik dan Sifat Fisik Rendang Daging. Jurusan Teknologi Hasil Pertanian. Fakultas Teknologi Pertanian. Universitas Jember. Kalimantan.

26. Prasetyo, F. dan Julianingsih. (2003). Penentuan Kondisi Pengolahan dan Penyajian Bumbu Rawon Instan Bubuk Dengan Metode Taguchi. Jurnal Teknik Industri. Vol 5. Pura, E. A., S.

27. Kusmajadi., dan S. Lilis. (2015). Pengaruh Berbagai Konsentrasi Daun Salam (Syzygiumpolyanthum) Terhadap Daya Awet dan Akseptabilitas Pa da Karkas Ayam Boiler. Jurnal Ilmu Ternak. Fakultas Peternakan. Universitas Padjajaran. Bandung.

28. Purnamasari, R. (2015). Pengaruh Jenis Pembusa dan Suhu Pengeringan Pada Pembuatan Serbuk Pewarna Alami Dari Kulit Buah Naga Merah (Hylocereus Polyrhizus) Dengan Metode FoamMat Drying. Program Studi Teknologi Pangan. Fakultas Teknik. Universitas Pasundan. Bandung.

29. Raghavan, U. S. (2007). Handbook of Spices, Seasonings, and Flavorings. 2nd Edition. CRC Press. Boca Raton, Florida

30. Rahim, A., Mappiratu, dan A. Noviyanty. (2009). Sifat Fisikokimia dan Sensoris Sohun
Instan Dari Pati Sagu. Jurusan Budidaya Pertanian. Fakultas Pertanian. Universitas Tadulako. Palu

31. Rumokoi, M. M., dan G. H. Joseph. (1993). Pengaruh Lama Pemisahan Skim dan Penyimpanan Terhadap Kualitas Minuman dari Santan Kelapa. J. Penelitian Kelapa.

32. Saadah, M., N. Nurdiana, dan W. Dwi. (2016). Uji Kadar Zat Warna ( $\beta$ karoten) Pada Cabe Merah (Capsicum annum.Linn) Sebagai Pewarna Alami. Jurusan Tadris IPA Biologi. FITK IAIN. Mataram

33. Sembiring, B.S., C. Winarti, dan B. Baringbing. (2003). Identifikasi komponen kimia minyak daun salam (Eugenia polyantha) dari Sukabumi dan Bogor. Buletin Tanaman Rempah dan Obat.

34. Soekarto. (1985). Penilaian Organoleptik Untuk Industri Pangan dan Hasil Pertanian. Pusat Pengembangan Teknologi Pangan, IPB, Bogor.

35. Sianipar, D. (2008). Kajian Formulasi Bumbu Instant Binthe Biluhuta, Karakteristik Hidratasi dan Pendugaan Umur Simpannya Dengan Menggunakan Metode Pendekatan Kadar Air Kritis. Sekolah Pascasarjana. Institut Pertanian Bogor. Bogor.

36. Srihari, E., F. S. Lingganingrum, R. Hervita, dan S. W. Helen. (2010). Pengaruh Penambahan Maltodekstrin Pada Pembuatan Santan Kelapa Bubuk. Seminar Rekayasa Kimia dan Proses.

37. Sudaryati., Latifah., dan E. H. Donny. (2013). Pembuatan Bubuk Cabe Merah Menggunakan Variasi Jenis Cabe dan Metode Pengeringan. Jurusan Teknologi Pangan. FTI UPN. Jawa Timur.

38. Suharyono, A. S., E. K. Maria, dan M. Kurniadi. (2009). Pengaruh Sinar Ultra Violet dan Lama Penyimpanan Mikrobiologi dan Ketengikan Krem Santan Kelapa. Agritech. Vol. 29. No. 3.

39. Sukasih, E., P. Sulusi, dan H. Tatang. (2009). Optimasi Kecukupan Panas Pada Pasteurisasi Santan dan Pengaruhnya Terhadap Mutu Santan Yang Dihasilkan. J. Pascapanen.

40. Tansakul, A. dan P. Chaisawang. (2006). Thermophysical Properties of Coconut Milk. J.Food Enginnering 73:276-280.

41. Tarwiyah, K. (2001). Tepung Aren. Jurnal Pengolahan Pangan Dewan Ilmu Pengetahuan, Teknologi dan Industri Sumatera Barat.

42. Van, W. B. M., Copley., dan A. I. Morgan. (1973). Food Dehydration. The AVI Publishing CO., Inc., Wespost. Conecticut.

43. Warsiki, E., E. Hambali., Suharmani., dan M. Z. Nasution. (1995). Pengaruh Jenis dan Konsentrasi Bahan Pengisi Terhadap Rancangan Produksi Tepung Instan Sari Buah Nanas. Jurnal. Tip. 5 (3) Hal: 172-178.

44. Wikipedia. (2016). Gulai. https://id.wikipedia.org/wiki/Gu lai. Diakses : 10-92016.

45. Wilde, P. J. dan D. C. Clark. (1996). Foam Formation and Stability Methods of Testing 
Protein Functionality. G. M. Hall, Blackie Academic \& Professional: 111-152..

46. Wilujeng, G. K. (2010). Pembuatan Inulin Bubuk Dari Umbi Gembili (Dioscorea esculenta) Dengan Metode Foam Mat Drying. Program Studi Teknologi Pangan. Fakultas Teknologi Industri. Universitas Pembangunan Nasional "Veteran". Surabaya.

47. Zubaedah, E., dan J. Kusnadi. (2003). Pembuatan Larutan Yoghurt dengan Metode Foam-Mat: Drying Kajian Penambahan Busa Putih Telur etrhadap Sifat Fisik dan Kimia. Teknologi Dan Industri Pangan, XIV(3), 258-261. 